\title{
Four-Tier Heat and Temperature Diagnostic Test (4T-HTDT) to Identify Student Misconceptions
}

\author{
Moh. Irma Sukarelawan ${ }^{1 *}$, Sriyanto², Ariati Dina Puspitasari ${ }^{3}$, Dwi Sulisworo $^{4}$, Ulfiana \\ Nurul Hikmah ${ }^{5}$ \\ 1,3,4,5 Universitas Ahmad Dahlan \\ Jl. Pramuka No.42, Kota Yogyakarta, Daerah Istimewa Yogyakarta, Indonesia \\ 2 SMAN 2 Bantul \\ JI. Ra. Kartini, Bantul, Daerah Istimewa Yogyakarta, Indonesia \\ *Email: moh.sukarelawan@mpfis.uad.ac.id
}

\begin{abstract}
There are limited studies on the diagnosis of heat and temperature misconceptions using a four-tier instrument diagnostic test. Therefore, this study aims to identify misconceptions in heat and temperature material. The survey research was conducted on 164 students at SMAN 2 Bantul. Students were selected using a convenience sampling technique. Identification of student misconceptions using the Four Tier Heat and Temperature Diagnostic Test (4T-HTDT). Students' conceptual understanding is calculated using the percentage technique. The results of this study indicate that there are still many students who have misconceptions on the concept of "heat-temperature as an extensive quantity" and "heat-temperature depends on material objects". The findings are expected to be a strategic step for designing appropriate remedial teaching.
\end{abstract}

Keywords: alternative conception, heat and temperature, misconception, four-tier diagnostic test

\section{INTRODUCTION}

The misconception is one of the classic problems that occur in the world of education. Until now, this misconception is still often experienced by students. Misconceptions are not only experienced by students in Indonesia (Angraini \& Prahmana, 2019; Izzati \& Rochmah, 2020; Nasrudin \& Azizah, 2020; Nisa et al., 2019; Ramadianti et al., 2019), but experienced by students in almost many countries in the world (Cox et al., 2016; Korur, 2015; Önder, 2016; Park \& Johnson, 2016; Taslidere, 2016; Tuysuz et al., 2016). Misconceptions also occur at every level of education. For example Elementary School (Anjarsari, 2018; Ramadianti et al., 2019), Junior High School (Ramadianti et al., 2019), Senior High School (Fenditasari et al., 2020; Lusiana et al., 2016; Wijaya et al., 2016), Undergraduate (Safriana \& Fatmi, 2018; Sholikah et al., 2020) and Postgraduate level (Eryilmaz, 2010; Sukarelawan et al., 2019). Students' misconceptions will impact understanding more complex advanced concepts so that the handling of students who experience misconceptions is essential.

Misconceptions are ideas, thoughts, ideas or explanations about a phenomenon that are not accurately supported by accepted physical principles (Türkmen, 2015). Apart from using the term misconception, various literature also shows that there are several other terms. For example: alternative conceptions, conceptual difficulties, misconceptions and others (Soeharto et al., 2019). Of the various terms used, misconception or alternative conception is a term that is more commonly used today. Misconceptions can come from physical experience, direct observation, intuition, teaching at school, teaching outside of school, social environment, culture, language, textbooks or other teaching materials, and teachers (Kaltakci-Gurel et al., 2016).

In the field of physics, misconceptions almost occur on various topics (e.g. Angraini \& Prahmana, 2019; Annisa, Astuti, \& Mindyarto, 2019; Kaniawati et al., 2019; Nisa et al., 2019; Safriana \& Fatmi, 2018; Slater, Morris, \& 
McKinnon, 2018; Wulandari, 2019). One of the most exciting topics to research is heat and temperature. Heat and temperature are fundamental topics in physics. Misconceptions on the topic of heat and temperature are urgent to study because it will impact subsequent mastery of material such as the kinetic theory of gases or thermodynamics. Apart from being used in physics, the topics of heat and temperature are also used in chemistry and engineering.

Various previous studies have analyzed misconceptions on the topic of temperature and heat (e.g. Alfiani, 2015; Aykutlu, Bezen, \& Bayrak, 2017; Fitriah, 2017; Putri, Suliyanah, \& Rohmawati, 2016; Silung, Kusairi, \& Zulaikah, 2016; Wahidah, Kusairi, \& Zulaikah, 2015). However, there is a limited study using the 4tier instrument in diagnosing heat and temperature misconceptions in students. The four-tier diagnostic test is an extension of the three-tier multiple-choice diagnostic test. This development is found in the added level of student confidence in choosing answers and reasons. Although the three-level test is considered validly identifying misconceptions that are free from error and lack of knowledge, it still has limitations because the level of confidence at the first and second levels is not differentiated. This situation can lead to two problems: (1). Underestimating the proportion of lack of knowledge, and (2). Too high scores of students' misconceptions (Kaltakçi, 2012). The advantage of the four-level diagnostic test is that teachers can: (1). Carry out a large number of misconceptions diagnostic tests on students, (2). Determining the state of the level of students' conceptual understanding is more accurate (3). Determine the part of the material that needs more emphasis (4). Can immediately plan lessons to reduce misconceptions that students own.

SMAN 2 Bantul is a school where the author serves. Therefore, the authors feel interested in identifying the misconceptions of heat and temperature experienced by students. As is well known, misconceptions experienced by students are individual. This means that the types of errors experienced by students may differ from one another. This research is one of the strategic steps to design remedial teaching that is personally oriented. This study aims to identify misconceptions in heat and temperature material in students of SMAN 2 Bantul using the Four Tier Heat and Temperature Diagnostic Test (4T-HTDT).

\section{METHOD}

This study used a survey research design conducted at SMAN 2 Bantul. This study involved 164 students as respondents (Male = $25.6 \%$ and Female $=74.4 \%$ ). Respondents were selected using a convenience sampling technique. The average age of the respondents was 16.6 years, with a standard deviation of 0.7 years.

Identification of student misconceptions using the 4T-HTDT. Items adapted from Sukarelawan et al. (Sukarelawan et al., 2019). The number of items used is 4 items. The item descriptions are presented in Table 1. Figure 1 is an example of a 4T-HTDT used. At the second and fourth tier, the confidence levels use a 6-level belief scale, from 1 (guessing only) to 6 (Very Strongly Sure). The level of conceptual understanding consists of Scientific Knowledge (SK), False Positive (FP), False Negative (FN), Lack of Knowledge (LK), and Misconception (Misc). The criteria for assessing the level of conceptual understanding refer to Table 2. The distribution of the conceptual understanding of students as a whole, students with misconceptions and students with scientific knowledge, is calculated using the percentage technique.

Table 1. Item Description

\begin{tabular}{|c|c|c|}
\hline No. & $\begin{array}{c}\text { Forms of } \\
\text { Misconception }\end{array}$ & Item Description \\
\hline 1 & $\begin{array}{l}\text { Temperature } \\
\text { as an } \\
\text { extensive } \\
\text { quantity }\end{array}$ & $\begin{array}{l}\text { Comparison of the } \\
\text { temperature of hand- } \\
\text { held large and small ice } \\
\text { cubes }\end{array}$ \\
\hline 2 & $\begin{array}{l}\text { The } \\
\text { temperature } \\
\text { depends on } \\
\text { the material }\end{array}$ & $\begin{array}{l}\text { Comparison of } \\
\text { temperature on the } \\
\text { aluminium table and } \\
\text { plastic table }\end{array}$ \\
\hline 3 & $\begin{array}{l}\text { Heat as an } \\
\text { extensive } \\
\text { quantity }\end{array}$ & $\begin{array}{l}\text { Comparison of the heat } \\
\text { of long and short metal } \\
\text { ruler }\end{array}$ \\
\hline 4 & $\begin{array}{l}\text { Heat depends } \\
\text { on the material }\end{array}$ & $\begin{array}{l}\text { Comparison of Heat of } \\
\text { metal and plastic ruler }\end{array}$ \\
\hline
\end{tabular}




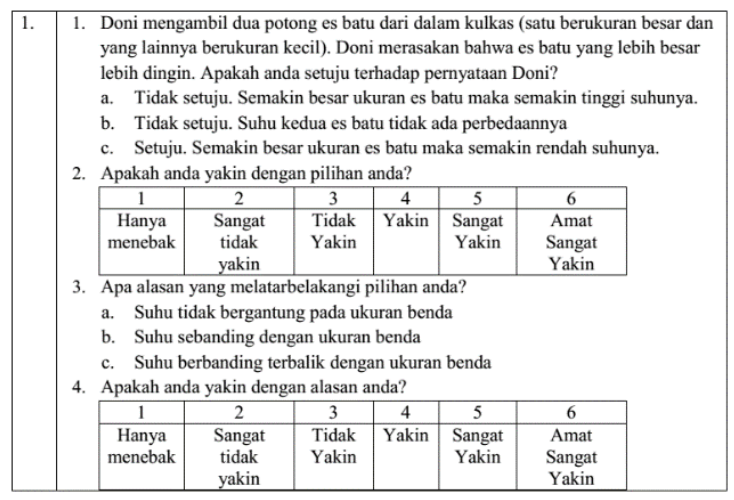

Figure 1. Example items in the 4T-HTDT

Table 2. Decision making for four-tier test

\begin{tabular}{ccccl}
\hline $1^{\text {st }}$ tier & $2^{\text {nd }}$ tier & $3^{\text {rd }}$ tier & $4^{\text {th }}$ tier & $\begin{array}{c}\text { Decision } \\
\text { making }\end{array}$ \\
\hline $\mathrm{C}$ & $>3,5$ & $\mathrm{C}$ & $>3,5$ & SK \\
$\mathrm{C}$ & $>3,5$ & $\mathrm{~W}$ & $>3,5$ & FP \\
$\mathrm{W}$ & $>3,5$ & $\mathrm{C}$ & $>3,5$ & FN \\
$\mathrm{W}$ & $>3,5$ & $\mathrm{~W}$ & $>3,5$ & Misc \\
$\mathrm{C}$ & $>3,5$ & $\mathrm{C}$ & $<3,5$ & LK \\
$\mathrm{C}$ & $<3,5$ & $\mathrm{C}$ & $>3,5$ & LK \\
$\mathrm{C}$ & $<3,5$ & $\mathrm{C}$ & $<3,5$ & LK \\
$\mathrm{C}$ & $>3,5$ & $\mathrm{~W}$ & $<3,5$ & LK \\
$\mathrm{C}$ & $<3,5$ & $\mathrm{~W}$ & $>3,5$ & LK \\
$\mathrm{C}$ & $<3,5$ & $\mathrm{~W}$ & $<3,5$ & LK \\
$\mathrm{W}$ & $>3,5$ & $\mathrm{C}$ & $<3,5$ & LK \\
$\mathrm{W}$ & $<3,5$ & $\mathrm{C}$ & $>3,5$ & LK \\
$\mathrm{W}$ & $<3,5$ & $\mathrm{C}$ & $<3,5$ & LK \\
$\mathrm{W}$ & $>3,5$ & $\mathrm{~W}$ & $<3,5$ & LK \\
$\mathrm{W}$ & $<3,5$ & $\mathrm{~W}$ & $>3,5$ & LK \\
$\mathrm{W}$ & $<3,5$ & $\mathrm{~W}$ & $<3,5$ & LK \\
\hline
\end{tabular}

$\mathrm{W}=$ Wrong; $\mathrm{C}=$ Correct; $\mathrm{SK}=$ Scientific Knowledge; FP = False Positive; FN = False Negative; Misc = Misconception; LK = Lack of Knowledge.

(Kaltakçi, 2012)

\section{RESULTS AND DISCUSSION}

\section{RESULTS}

The average distribution of students' conceptual understanding

The average distribution of students' conceptual understanding of heat-temperature misconception as an extensive quantity and heat-temperature depending on the material is shown in Figure 2.

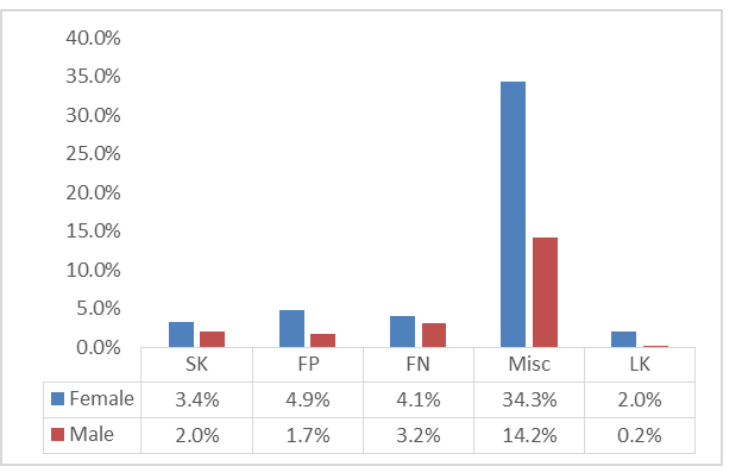

Figure 2. Distribution of students' conceptual understanding

Figure 2 shows that almost half of the respondents experienced misconceptions (48.5\%). The dominant female gender experienced misconception as much as $34.3 \%$ and male as much as $14.2 \%$. Apart from experiencing misconceptions, the number of students who experienced a lack of knowledge was $31.8 \%$. Female students who experience lack of knowledge are 7 times that of male. Only $5.4 \%$ of students have Scientific Knowledge (3.4\% Female and $2.0 \%$ Male).

Meanwhile, the conceptual understanding of FP and FN was $6.3 \%$ and $7.3 \%$, respectively. Based on Figure 2 , it appears that the number of students with misconceptions and Scientific Knowledge is at the maximum and minimum scores. So that further analysis is needed.

\section{Distribution of student misconceptions}

The results of the identification of students who experience misconceptions in more detail are shown in Figure 3.

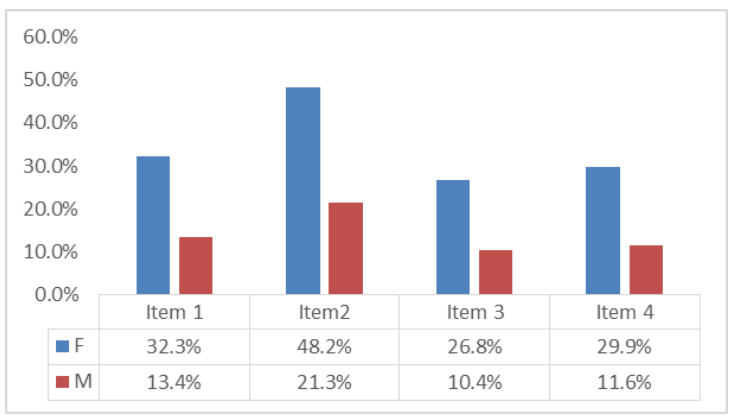

Figure 3. Students who experience misconceptions

Based on Figure 3, students experienced the most misconceptions in item 2 at $69.5 \%$. As 
many as $45.7 \%$ of students had misconceptions in item $1,41.5 \%$ of students had misconceptions in item 4 , and $37.2 \%$ of students had misconceptions on item 3 . Item 2 "Temperature depends on material objects" was the concept with the most misconceptions. As many as $48.2 \%$ experienced by female students, and $21.3 \%$ experienced by male students. While item 3 "Heat as an extensive quantity" is the concept with the least misconceptions. As many as $26.8 \%$ experienced by female students, and $10.4 \%$ experienced by male students.

\section{Distribution of Student Scientific Knowledge}

The results of identification of students who have Scientific Knowledge are depicted in Figure 4.

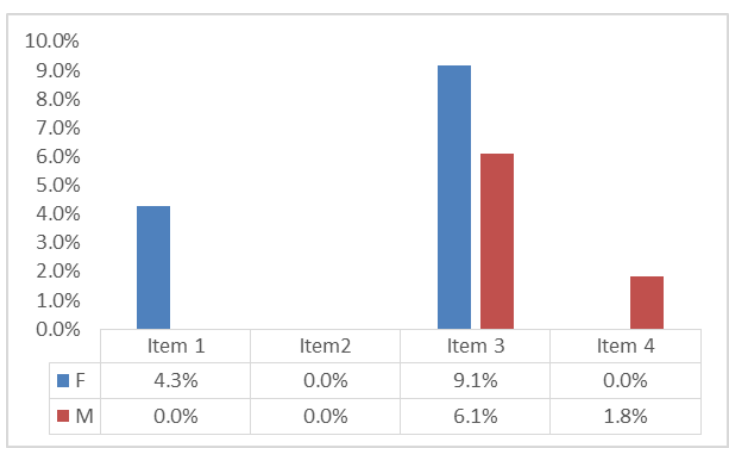

Figure 4. Students who experience Scientific Knowledge

Based on Figure 4, it was identified that $15.2 \%$ of students experienced scientific knowledge in item 3. As many as $4.3 \%$ of students had scientific knowledge on item 1. Meanwhile, in items 4 and 2, $1.8 \%$ and $0 \%$, respectively. Item 3 "Heat as an extensive quantity" is most well understood by students, namely $9.1 \%$ by female students and $6.1 \%$ by male students. While item 2 "Temperature depends on material objects", both male and female students, none of the students had scientific knowledge.

\section{DISCUSSION}

This study aims to identify the misconceptions that high school students have using 4T-HTDT. The 4-tier instrument is considered an ideal instrument to diagnose large-scale respondents' misconceptions (Liu et al., 2011). Based on the analysis results, the average student who experienced misconceptions was the highest compared to other levels of conceptual understanding. The form of conceptual understanding in the form of Lack of Knowledge is in second placemeanwhile, students who have the lowest understanding of Scientific Knowledge.

When viewed based on the form of misconception, many students understand that an object's temperature depends on the material that makes up the object. This can be understood when we touch two objects made of different materials, metal and non-metal. It will seem that metal objects are cooler than nonmetals. When two objects are in the same room for a long enough time, the two objects' temperature will experience thermal equilibrium with the ambient temperature. In other words, the temperature of the two objects is the same. In principle, metal objects that seem cooler are not the same as objects that have low temperatures. Metal objects feel cooler to the touch due to differences in metals and nonmetals to absorb/conduct heat. When touched, more heat flows from the hands to the metal than towards the non-metals because metals can absorb heat better than non-metals. This is what gives students the impression that metal objects have a lower temperature than nonmetal objects. Students who experience misconceptions cannot be corrected by ordinary learning because the concept that is understood is believed to be true. Need special treatment to reduce misconceptions that are owned. Teachers need to design exceptional learning that can change the understanding and beliefs that these students have. One of the learning models that can be used to reduce misconceptions is Posner's conceptual change learning model (Soysal, 2020). This learning model offers a series of stages in embedding more precise concepts. One of the stages is to raise doubts in students about the concepts they currently understand.

Based on the analysis of students who understand scientific knowledge, only a small proportion of students understand the scientific knowledge of the four concepts that were tested. As many as $15.2 \%$ of students 
understand very well that the heat possessed by an object is an intensive quantity. This means that the object's dimensions do not affect the heat it contains when two objects are in the same room for quite a long time. Whereas in the concept of "temperature depends on material objects", none of the students understood correctly. The distribution of students' conceptual understanding is in False Negative, False Positive, Misconception and Lack of Knowledge. False Positive conditions occur because students do not understand the reasons why a concept applies but are believed to be true.

Meanwhile, the False Negative condition is a condition where students understand the reason for a concept to be valid but do not understand the existing concept's truth. The terms False Negative and False Positive are also known as deficiency understanding and less information (Hestenes \& Halloun, 1995). False Positive conditions are more challenging to repair than False Negative conditions (Istiyani et al., 2018).

This finding does not only occur in high school students but also at lower and higher levels of education as previously reported (Baser, 2006; Chu et al., 2012; Eryilmaz, 2010; Gurcay \& Gulbas, 2015; Paik et al., 2007; Sukarelawan et al., 2019; Yeo \& Zadnik, 2001).

\section{ACKNOWLEDGEMENT}

This research was funded by the Research and Community Services Institute of Ahmad Dahlan University (LPPM-UAD).

\section{CONCLUSION}

Based on the findings previously described, students still experience a misconception of the concept of "heattemperature as an extensive quantity" and "heat-temperature depends on material objects". On average, students who experienced misconceptions were $48.5 \%$, and scientific knowledge was $5.4 \%$. As many as $69.5 \%$ of students experienced a misconception on the concept of "Temperature depends on material objects", and only 15.2\% of students understood the concept of "Heat as an extensive quantity".

These findings make a significant contribution to teachers who teach heat and temperature material. For teachers, the identification results that have been done can be used as a first step in designing effective learning. For schools, it can facilitate teachers to have skills in designing various effective learning models to reduce misconceptions. These findings are limited in identifying students' conceptual understanding. Further research can be developed to reveal the source of the misconceptions that occur. So that more comprehensive information is obtained.

\section{REFERENCES}

Alfiani. (2015). Analisis Profil Miskonsepsi dan Konsistensi Konsepsi Siswa SMA pada Topik Suhu dan Kalor. Prosiding Seminar Nasional Fisika (E-Journal) SNF2015, IV, 29-32.

Angraini, P., \& Prahmana, R. C. I. (2019). Misconceptions of seventh grade students in solving geometry problem type national examinations. Journal of Physics: Conference Series, 1188(1), 012101. https://doi.org/10.1088/17426596/1188/1/012101

Anjarsari, P. (2018). The Common Science Misconceptions in Indonesia Junior High School Students. Journal of Science Education Research, 2(1), 2124.

Annisa, R., Astuti, B., \& Mindyarto, B. N. (2019). Tes Diagnostik Four Tier untuk Identifikasi Pemahaman dan Miskonsepsi Siswa pada Materi Gerak Melingkar Beraturan. Jurnal Pendidikan Fisika Dan Keilmuan, 05(1), 25-32.

Aykutlu, I., Bezen, S., \& Bayrak, C. (2017). An Assessment of High School Students' Conceptual Structures of Heat And Temperature Through Concept Maps. AIP Conference Proceedings, 1815(1), 1-4. https://doi.org/10.1063/1.4976423

Baser, M. (2006). Effect of Conceptual Change Oriented Instruction on Students' Understanding of Heat and Temperature Concepts. Journal of 
Maltese Education Research, 4(1), 6479.

Chu, H.-E., Treagust, D. F., Yeo, S., \& Zadnik, M. (2012). Evaluation of Students' Understanding of Thermal Concepts in Everyday Contexts. International Journal of Science Education, 34(10), 1509-1534.

https://doi.org/10.1080/09500693.2012 .657714

Cox, M., Steegen, A., \& de Cock, M. (2016). How Aware Are Teachers of Students' Misconceptions in Astronomy? A Qualitative Analysis in Belgium. Science Education Internatioal, 27(2), 277-300.

Eryilmaz, A. (2010). Development and Application of Three-Tier Heat and Temperature Test: Sample of Bachelor and Graduate Students. Eurasian Journal of Educational Research, (40), 53-76.

Fenditasari, K., Jumadi, Istiyono, E., \& Hendra. (2020). Identification of misconceptions on heat and temperature among physics education students using fourtier diagnostic test. Journal of Physics: Conference Series, 1470, 012055. https://doi.org/10.1088/17426596/1470/1/012055

Fitriah, L. (2017). Diagnosis Miskonsepsi Siswa pada Materi Kalor dengan Menggunakan Three-Tier Essay dan Open-Ended Test. Berkala IImiah Pendidikan Fisika, 5(2), 168-181.

Gurcay, D., \& Gulbas, E. (2015). Development of three-tier heat, temperature and internal energy diagnostic test. Research in Science \& Technological Education, 33(2), 197-217. https://doi.org/10.1080/02635143.2015 .1018154

Hestenes, D., \& Halloun, I. (1995). Interpreting the force concept inventory: A response to March 1995 critique by Huffman and Heller. The Physics Teacher, 33(8), 502-502. https://doi.org/10.1119/1.2344278

Istiyani, R., Muchyidin, A., \& Raharjo, H. (2018). Analysis of Student Misconception on Geometry Concepts Using Three-Tier Diagnostic Test. Jurnal Cakrawala
Pendidikan, 37(2), 223-236. https://doi.org/10.21831/cp.v37i2.1449 3

Izzati, S., \& Rochmah, N. (2020). Analysis of Students' Comprehension and Misconception towards the Topic of Salt Solubility. Jurnal Penelitian Dan Pembelajaran IPA, 6(1), 152. https://doi.org/10.30870/jppi.v6i1.7324

Kaltakci-Gurel, D., Eryilmaz, A., \& McDermott, L. C. (2016). Identifying Pre-Service Physics Teachers' Misconceptions and Conceptual Difficulties about Geometrical Optics. European Journal of Physics, 37(4), 1-30.

Kaltakçi, D. (2012). Development and Application Of A Four-Tier Test To Assess Pre-Service Physics Teachers' Misconceptions About Geometrical Optics.

Kaniawati, I., Fratiwi, N. J., Danawan, A., Suyana, I., Samsudin, A., \& Suhendi, E. (2019). Analyzing students' misconceptions about Newton's Laws through Four-Tier Newtonian Test (FTNT). Journal of Turkish Science Education, 16(1), 110-122. https://doi.org/10.12973/tused.10269a

Korur, F. (2015). Exploring seventh-grade students' and pre-service science teachers' misconceptions in astronomical concepts. Eurasia Journal of Mathematics, Science and Technology Education, 11(5), 10411060.

Liu, O. L., Lee, H.-S., \& Linn, M. C. (2011). An Investigation of Explanation MultipleChoice Items in Science Assessment. Educational Assessment, 16(3), 164184.

https://doi.org/10.1080/10627197.2011 .611702

Lusiana, N., Kurniawati, L., \& Mulyanto, A. B. (2016). Analisis Miskonsepsi Siswa Pokok Bahasan Momentum Dan Impuls Di Kelas XII IPA.4 SMA Negeri 4 Lubuklinggau Tahun Pelajaran 2015/2016.

Nasrudin, H., \& Azizah, U. (2020). Overcoming Misconception in Energetic Topics Through Implementation of Metacognitive Skills-Based 
Instructional Materials: A Case Study in Student of Chemistry Department, Universitas Negeri Surabaya. Jurnal Pendidikan IPA Indonesia, 9(1), 125134. https://doi.org/10.15294/jpii.v9i1. 21630

Nisa, F., Yuliati, L., \& Mufti, N. (2019). Miskonsepsi Konsep Gerak Satu dan Dua Dimensi Siswa SMA. Jurnal Pendidikan, 4(10), 1380-1385.

Önder, F. (2016). Surveying college introductory physics students attitudes and approaches to problem solving Development and validation of the photoelectric effect concept inventory. European Journal of Physics, 37, 1-18. https://doi.org/10.1088/01430807/37/5/055709

Paik, S., Cho, B., \& Go, Y. (2007). Korean 4- to 11-Year-Old Student Conceptions of Heat and Temperature. Journal of Research in Science Teaching, 44(2), 284-302.

Park, M., \& Johnson, J. A. (2016). Evaluation of Students' Energy Conception in Environmental Science. International Journal of Environmental \& Science Education, 11(12), 5572-5590.

Putri, H. N. P. A., Suliyanah, \& Rohmawati, L. (2016). Identifikasi Kualitas Instrumen Soal Three-Tier Diagnostic Test Pada Materi Suhu, Kalor dan Perpindahannya. Jurnal Inovasi Pendidikan Fisika (JIPF), 05(03), 216219.

Ramadianti, W., Priatna, N., \& Kusnandi. (2019). Misconception analysis of junior high school student in interpreting fraction. Journal for the Education of Gifted Young Scientists, 7(4), $\quad$ 1159-1173. https://doi.org/10.17478/jegys.631567

Safriana, S., \& Fatmi, N. (2018). Analisis Miskonsepsi Materi Mekanika pada Mahasiswa Calon Guru Melalui Force Concept Inventory dan Certainty of Response Index. Jurnal Pendidikan Sains Indonesia, 6(2), 90-94. https://doi.org/10.24815/jpsi.v6i2.1189 7

Sholikah, A., Febriyanti, D. S., \& Kurniawan, B. R. (2020). Analisis Miskonsepsi
Mahasiswa Calon Guru Fisika Menggunakan Quizziz Pada Pokok Bahasan Optika Geometri. Jurnal Penelitian Pembelajaran Fisika, 11(1), 27. https://doi.org/10.26877/jp2f.v11i1.415 2

Silung, S. N. W., Kusairi, S., \& Zulaikah, S. (2016). Diagnosis Miskonsepsi Siswa SMA di Kota Malang pada Konsep Suhu dan Kalor Menggunakan Three Tier Test. Jurnal Pendidikan Fisika Dan Teknologi, II(3), 95-105.

Slater, E. V., Morris, J. E., \& McKinnon, D. (2018). Astronomy alternative conceptions in pre-adolescent students in Western Australia. International Journal of Science Education, 40(17), 2158-2180.

https://doi.org/10.1080/09500693.2018 .1522014

Soeharto, Csapó, B., Sarimanah, E., Dewi, F. I., \& Sabri, T. (2019). A Review of Students' Common Misconceptions in Science and Their Diagnostic Assessment Tools. Jurnal Pendidikan IPA Indonesia, 8(2), 247-266. https://doi.org/10.15294/jpii.v8i2.18649

Soysal, Y. (2020). Establishing the norms of the Vygotskian teaching in the science classroom. Elementary Education Online, 19(3), 1838-1857. https://doi.org/10.17051/ilkonline.2020. 735202

Sukarelawan, M. I., Jumadi, J., \& Rahman, N. A. (2019). An Analysis of Graduate Students' Conceptual Understanding in Heat and Temperature ( $H$ \& $T)$ Using Three-Tier Diagnostic Test. Indonesian Review of Physics, 2(1), 9-14. https://doi.org/10.12928/irip.v2i1.910

Taslidere, E. (2016). Development and use of a three-tier diagnostic test to assess high school students' misconceptions about the photoelectric effect. Research in Science \& Technological Education, 34(2), 164-186. https://doi.org/10.1080/02635143.2015 .1124409

Türkmen, H. (2015). After Almost Half-Century Landing On The Moon And Still Countering Basic Astronomy 
Conceptions. European Journal Of Physics Education, 6(2), 1-17. https://doi.org/10.20308/ejpe.70434

Tuysuz, M., Bektas, O., Geban, O., Ozturk, G., \& Yalvac, B. (2016). Pre-Service physics and chemistry teachers' conceptual integration of physics and chemistry concepts. Eurasia Journal of Mathematics, Science and Technology Education, 12(6), 1549-1568. https://doi.org/10.12973/eurasia.2016. $1244 a$

Wahidah, S. N., Kusairi, S., \& Zulaikah, S. (2015). Identifikasi Miskonsepsi Siswa SMA pada Materi Suhu dan Kalor serta Kemungkinan Penyebabnya. Seminar Nasional Jurusan Fisika FMIPA UNESA 2015, 180-185.

Wijaya, C. P., H, S. K., \& Muhardjito. (2016). The Diagnosis Of Senior High School Class $X$ MIA B Students Misconceptions About Hydrostatic Pressure Concept Using Three-Tier. Jurnal Pendidikan IPA Indonesia, 5(1), 14-21. https://doi.org/10.15294/jpii.v5i1.5784

Wulandari, F. (2019). Miskonsepsi Siswa Tentang Suhu Dan Kalor Menggunakan Test Diagnotis Di Sma Negeri 1 Sejangkung. Journal of Chemical Information and Modeling, 53(9), 1689-1699. https://doi.org/10.1017/CBO97811074 15324.004

Yeo, S., \& Zadnik, M. (2001). Introductory thermal concept evaluation: assessing students' understanding. The Physics Teacher, 39(8), 496-504. https://doi.org/10.1119/1.1424603 